\title{
Aktualne tendencje w projektowaniu żłobków i przedszkoli i ich wpływ na rozwój dzieci. Studium wybranych realizacji z uwzględnieniem dostępu do przyrody
}

Current trends in the design of nurseries and kindergartens and their impact on the development of children. Study of selected projects including access to nature

\section{Streszczenie:}

W artykule poruszono problematykę architektury współczesnych żłobków i przedszkoli oraz zwrócono uwagę na ich dostęp do przyrody i zieleni na podstawie analizy istniejących obiektów w Polsce oraz wybranych obiektów europejskich i azjatyckich. Opisano podstawowe założenia teoretyczne dotyczące potrzeb dziecka w aspekcie architektury oraz kontaktu z naturą, które zestawiono z realiami panującymi w tego typu inwestycjach.

Przedstawiono najczęstsze i najbardziej istotne cechy dominujące architekturę żłobków i przedszkoli a także jej otoczenie oraz poddano analizie w kontekście rzeczywistych potrzeb dla danej kategorii wiekowej. Podjęto próbę oceny najczęstszych czynników przyrodniczego wyjałowienia terenów przedszkolnych oraz nakreślono zagrożenia jakie niesie ze sobą kontynuowanie takiego podejścia.

Przyjęte metody badań obejmowały m.in. analizę opracowań naukowych z zakresu architektury, psychologii i kognitywistyki oraz obserwacje i eksperymenty wśród grupy docelowej (dzieci z przedziału wiekowego 3-5 lat).

\begin{abstract}
:
The article discusses the issues of the architecture of contemporary nurseries and kindergartens, and highlights their access to nature and greenery based on the analysis of existing facilities in Poland and selected European and Asian facilities. The basic theoretical assumptions regarding the child's needs in terms of architecture and contact with nature were described, compared to the realities of this type of investment.

The most common and important features dominating the architecture of nurseries and kindergartens as well as its surroundings were presented and analyzed in the context of actual needs for a given age category. An attempt was made to assess the most common factors of the natural depletion of pre-school grounds and outlined the risks of continuing such an approach.

The adopted research methods included, among other, analysis of scientific studies in the field of architecture, psychology and cognitive science as well as observations and experiments among the target group (children aged 3-5).
\end{abstract}

Słowa kluczowe: architektura dla dzieci, wpływ architektury i otoczenia na rozwój człowieka, architektura i przyroda w kontekście obiektów oświatowych

Key words: architecture for children, the influence of architecture and surroundings on human development, architecture and nature in the context of educational facilities 


\section{WPROWADZENIE}

“Nikt nie będzie chronił tego na czym mu nie zależy i nikomu nie będzie zależeć na tym, czego nigdy nie doświadczył"1 - tymi słowami David Attenborough ${ }^{2}$ opisuje jeden z poważniejszych problemów dzisiejszego świata jakim jest coraz słabsza integracja człowieka z przyrodą. Nierzadko w mediach ${ }^{3}$ przedstawiany jest ogrom skali i wielowymiarowość tego problemu, co stanowi przytłaczające i dosyć ponure poczucie niemocy. Jednak należy pamiętać, że każdy ma możliwość wprowadzenia pewnych zmian a podjęte działania- lokalne i na mniejszą skalę- są w stanie skutecznie wypracować mechanizmy skutkujące zwiększeniem świadomości danego problemu i eliminacją go w przyszłości. W ten sam sposób warto również spojrzeć na środowisko w którym dorastają dzieci - żłobki czy przedszkola ponieważ to w tych obiektach, oprócz miejsca zamieszkania, kształtują się pierwsze metody radzenia sobie ze stresem czy sposób podejścia do otaczającego świata. Jako paradygmat przyjmuje się, że kontakt z naturą ma pozytywny wpływ na rozwój dzieci, co nie oznacza, że przez jego oczywistość należy rozważania na ten temat porzucić. Należy przede wszystkim zastanowić się jak ta teoria przekłada się na praktykę. S Tillman (2018) wraz z współautorami przeprowadziła interesujące badania dotyczące korzyści dla zdrowia psychicznego dzieci wynikające z interakcji z naturą ${ }^{4}$. Dowiodły one, że dostęp do natury w większości wpływa pozytywnie na ogólny stan psychiczny zarówno u osób z zaburzeniami u których łagodzi objawy (ADHD, depresja, przewlekły stres) jak i dzieci bez tego typu problemów. Podobne wyniki uzyskano we wcześniejszych badaniach, gdzie udowodniono, że dzieci narażone na długotrwały stres lub traumy lepiej radzą sobie z nimi żyjąc w miejscach bliżej związanych z naturą niż w terenach mocno zurbanizowanych (Wells NM, Evans GW, 2003). Z kolei M. Mohammadi (2017) w swoim artykule wyróżnia typy przestrzeni, które dzieci postrzegają jako atrakcyjne i czują się w nich bezpiecznie i komfortowo:

- naturalne przestrzenie z zadrzewieniem, akwenami wodnymi oraz naturalnie występującą fauną (podkreśla je jako najbardziej istotne),

- otwarte przestrzenie: miejsca w których aktywności takie jak np. bieganie są nieograniczone żadnymi elementami i pozwalają na wyładowanie skumulowanej energii

- przestrzenie publiczne budzące emocje (indywidualne dla każdego dziecka bądź wybranej grupy)

- przestrzenie "do przygód”

- przestrzenie ukryte (kryjówki, miejsca trudno dostępne dla dorosłego) (Alexander Ch., 2008).

$\mathrm{W}$ artykule podjęto próbę oceny faktycznego dostępu do przyrody w wybranych realizacjach żłobków i przedszkoli w środowisku mieszkaniowym. Podjęto próbę oceny (przez pryzmat wspomnianych i podjętych przez autorkę badań) jak architektura i dostęp do przyrody w wybranych obiektach opiekuńczo-edukacyjnych dla dzieci może wpływać na ich rozwój oraz podejście do środowiska naturalnego.

\section{INTRODUCTION}

“No one will protect what he doesn't care about, and no one will care about what he has never experienced"1 - with these words David Attenborough ${ }^{2}$ describes one of the most serious problems of the world today, which is the decreasing integration of man with nature. It is not uncommon in the me$\mathrm{dia}^{3}$ to portray the enormity of the scale and multidimensionality of this problem, which creates an overwhelming and rather grim sense of impotence. However, it should be remembered that everyone has the opportunity to make some changes, and actions taken - local and on a smaller scale - can effectively develop mechanisms resulting in increased awareness of the problem and its elimination in the future. In the same way, it is worth looking at the environment in which children grow up - nurseries or kindergartens - because it is in these facilities, apart from the place where they live, that the first methods of coping with stress and the way they approach the surrounding world are formed. It is accepted as a paradigm that contact with nature has a positive impact on the development of children, which does not mean that by its obviousness we should abandon consideration of this topic. The main thing to consider is how this theory translates into practice. S Tillman (2018) and her co-authors conducted an interesting study on the mental health benefits of interacting with nature for children ${ }^{4}$. They found that access to nature mostly has a positive effect on overall mental health in both those with disorders in which it alleviates symptoms (ADHD, depression, chronic stress) and children without such problems. Similar results were obtained in earlier studies, where it was proved that children exposed to long-term stress or trauma cope better with them living in places closer to nature than in heavily urbanized areas (Wells NM, Evans GW, 2003). As well M. Mohammadi (2017) in his article distinguishes the types of spaces that children perceive as attractive and feel safe and comfortable in:

- natural spaces with trees, bodies of water, and naturally occurring fauna (he highlights these as the most important),

- open spaces: places where activities such as running are unconstrained by any elements and allow us to release our accumulated energy

- public spaces with emotions (individual for each child or group)

- spaces "for adventure".

- hidden spaces (hiding places, places difficult to access for an adult) (Alexander Ch., 2008).

This paper attempts to assess the actual access to nature in selected projects of nurseries and kindergartens in a residential environment. An attempt was made to assess (through the prism of the research mentioned and undertaken by the author) 


\section{METODYKA BADAŃ I KRYTERIA WYBORU}

Celem głównym artykułu jest próba określenia roli architektury i przyrody w rozwoju człowieka w wieku do 5 lat przy uwzględnieniu żłobków i przedszkoli znajdujących się na terenach zurbanizowanych, w szczególności na terenach mieszkaniowych. W przypadku realizacji z Polski jako główne kryteria wyboru przyjęto do analizy porównawczej obiekty samorządowe będące typowymi realizacjami z końca XX wieku oraz najnowsze realizacje $z$ ostatnich 5 lat. Dla realizacji z Europy jako przykład przyjęto publiczną placówkę realizującą metody Reggio Emilia, która w swym statucie deklaruje bliskość człowieka z naturą oraz wolność jednostki, a więc założenia, które w aktualnych i wymienionych przez autorke badaniach podawane są jako kluczowe w rozwoju dzieci. Realizacja z Azji to nowatorskie przedszkole publiczne, które spotkało się z krytyką urzędników w początkowej fazie projektowej a następnie okazało się jednym z najbardziej funkcjonalnych i nagradzanych w swej dziedzinie obiektem. Uzasadniając wybór tematu badawczego przyjęto następujące hipotezy badawcze:

1. Obcowanie od pierwszych lat życia z przyrodą oraz architekturą, która spełnia zasady ładu przestrzennego, cechuje się dobrym designem i funkcjonalnością skutkuje pobudzeniem zmysłów odpowiedzialnych za poczucie estetyki, które zaś - w szerszej perspektywie- przełożyć się mogą na minimalizowanie chaosu urbanistycznego i architektonicznego w świecie przyszłych pokoleń.

2.Przestrzeń architektoniczna oraz tereny zielone mają ogromny wpływ na rozwój psychologiczny i fizyczny dziecka, zwłaszcza w okresie wczesnego dzieciństwa, w związku z czym placówki wychowawczo- edukacyjne powinny kłaść większy nacisk na rolę otoczenia i architektury.

3. Architektura żłobków i przedszkoli w Polsce - w znacznej skali - nie spełnia potrzeb dzieci w ich poszczególnych fazach rozwoju.

Jako metody badawcze przyjęto m.in.:

- metodę obserwacyjno-eksperymentalną (prowadzone przez autorkę półroczne warsztaty architektoniczne w Samorządowym Przedszkolu nr 55 w Krakowie w ramach współpracy z Narodowym Centrum Kultury "Archiprzygody"),

- metodę indywidualnych przypadków (analiza wybranych projektów i realizacji architektonicznych),

- metodę analizy piśmiennictwa,

- metodę konstrukcji logicznej.

\section{CZŁOWIEK I ŚRODOWISKO NATURALNE}

W psychologii jako paradygmat przyjmuje się, że otoczenie przyrody ma pozytywny wpływ na zdrowie psychiczne ${ }^{5}$ i ogólną kondycje człowieka. Bliskość otwartej zieleni, parków czy akwenów wodnych w dużym stopniu determinuje ocenę jakości życia ${ }^{6} w$ mieście. Jest to oczywiście tylko jeden z wielu czynników mających wpływ na samopoczucie, za to jeden z nielicznych, na które architekci mają realny wpływ. Zapewnienie dostępu do how architecture and access to nature in selected child care and educational facilities can influence their development and attitude towards the natural environment.

\section{RESEARCH METHODOLOGY AND SELECTION CRITERIA}

The main aim of the article is to try to define the role of architecture and nature in human development up to the age of 5, taking into account nurseries and kindergartens located in urbanized areas, in particular in residential areas. The following were used as the main selection criteria needed to undertake the comparative analysis: nurseries and local government kindergartens, which are typical realizations from the end of the 20th century and the latest projects from the last 5 years. For realizations from Europe, as an example, a public institution implementing the Reggio Emilia methods was adopted, which in it is statute declares the closeness of man with nature and the freedom of the individual, i.e. assumptions that are given in the current research and mentioned by the author as key in the development of children. The project from Asia is an innovative public kindergarten, which met with criticism from officials in the initial design phase and then turned out to be one of the most functional and awarded facilities in its field. Justifying the choice of the research topic, the following research hypotheses were adopted:

1. Communion from the first years of life with nature and architecture that meets the principles of spatial order, is characterized by good design and functionality, stimulates the senses responsible for the sense of aesthetics, which - in a wider perspective - may contribute to minimizing urban and architectural chaos in the world future generations.

2. Architectural space and green areas have a huge impact on the psychological and physical development of a child, especially in early childhood, therefore educational institutions should place greater emphasis on the role of the environment and architecture.

3. The architecture of nurseries and kindergartens in Poland - to a large extent - does not meet the needs of children in their individual stages of development.

The following research methods were adopted:

- the observational-experimental method (conducted by the author six months long architecture workshops at the public kindergarten No. 55 in Krakow in cooperation with the National Center for Culture "Archiprzygody")

- the method of individual cases (analysis of selected projects and architectural realizations),

- literature analysis method,

- method of logical construction. 
zieleni w życiu codziennym, zwłaszcza w dzisiejszych czasach, wydaje się być jednym z głównych wyzwań projektowych. Nie tylko z uwagi na poprawę jakości życia, ale także ze względu na budowanie świadomości ekologicznej, która jest niezwykle ważna w kontekście przyszłości naszej planety. Nie można wyróżnić jednego właściwego etapu w którym należałoby „wyuczyć" w człowieku tzw. świadomość ekologiczną, ponieważ jest to proces złożony. Istnieje natomiast szereg badań ${ }^{7}$ przedstawiających fakty dotyczące szczególnej chłonności umysłu do piątego roku życia (Skibska J., 2015). Chłonność ta oznacza m.in., że w dzieciństwie mózg gotowy jest na przetworzenie i zapamiętanie wielu informacji, jednak aby tak się stało konieczny jest stały kontakt z danym czynnikiem (Blakemore, S.J. i Frith, U., 2008). Dodatkowo w procesie tym istotne są stadia rozwoju poznawczego (wg Piageta), w których to właśnie wiek 0-2 lata jest określany jako tzw. stadium inteligencji sensomotorycznej - wiek w którym człowiek uczy się poprzez bezpośrednie doświadczenie. Z kolei od drugiego do szóstego roku życia mamy do czynienia ze stadium przedoperacyjnym, gdzie główne znaczenie dla rozwoju ma eksperymentowanie na przedmiotach (Harwas-Napierała B., Trempała J., 2014) W związku z tym, aby wyrobić pewne nawyki należy wprowadzić niezbędne elementy do stałego otoczenia, by później stały się one czymś naturalnym. Na tej podstawie można więc wysnuć tezę, że najlepszym momentem na rozpoczęcie budowania świadomości ekologicznej jest okres wczesnego dzieciństwa, a najlepszym miejscem są przedszkola czy żłobki biorąc pod uwagę ich kulturotwórczy i opiniotwórczy charakter oraz ilość czasu jaki spędzają w nich dzieci. Dodatkowo badania wskazują, że związek z naturą jest głębszy u osób, które w okresie dzieciństwa były bliżej przyrody i spędzały na jej łonie więcej czasu. Warto również zwrócić uwagę, że dzieci w wieku przedszkolnym wyrażają chęć przebywania w obiektach, które jednocześnie zapewniają dostęp do takich elementów jak zieleń, woda, niejednolite ukształtowanie terenu czy nawet kontakt ze zwierzęta$\mathrm{mi}^{8}$.W Polsce temat terenów zielonych przy obiektach "Wczesnodziecięcych" nie jest poruszany zbyt często, z pewnością nie jest stawiany jako jeden z najbardziej istotnych elementów rozwoju człowieka. Badacze Emilia i Jan Frątczakowie podkreślali ogromną wagę zakładania ogródków przy przedszkolach, a już 1977 roku wydali książkę "Ogród przedszkolny" opisującą istotę powstawania tych przestrzeni oraz tego jak ważny mają wpływ na rozwój dziecka. Anna Klichowska w swoim artykule ${ }^{9}$ klasyfikuje zaś funkcje ogrodu opracowane przez Stanisława Raczkowskiego, który wskazuje „funkcję zdrowotną i biologiczną, społeczną i wychowawczą oraz estetyczną" (Klichowska A., 2013). Klasyfikacja tych cech przypomina nieco w swej strukturze piramidę Maslowa. Funkcja zdrowotna i biologiczna odnosi się do fizycznych cech zieleni, która poprzez swoje właściwości i/lub strukturę oczyszcza powietrze, chroni przed wiatrem, daje cień czy redukuje hałas. Funkcja społeczna i wychowawcza określa m.in. naukę poszanowania przyrody

\section{HUMAN AND NATURAL ENVIRONMENT}

In psychology, it is assumed as a paradigm that the environment of nature has a positive impact on mental health ${ }^{5}$ and the general condition of a person. The proximity of open green spaces, parks, or water reservoirs largely determines the quality of life ${ }^{6}$ in the city. This is, of course, only one of many factors that affect well-being, but one of the few that architects and city planners have a real influence on. Providing access to the greenery in everyday life, especially nowadays, seems to be one of the main design challenges. Not only to improve the quality of life but also to build environmental awareness, which is extremely important in the context of the future of our planet. It is impossible to distinguish one appropriate stage in which it would be necessary to "teach" the socalled environmental awareness as it is a complex process. On the other hand, there are a number of studies ${ }^{7}$ presenting facts about the special receptivity of the mind up to the age of five (Skibska J., 2015). This absorbency means, among others, that in childhood the brain is ready to process and remember a lot of information, but for this to happen, constant contact with a given factor is necessary (Blakemore, S.J. and Frith, U., 2008). Also, the stages of cognitive development (according to Piaget) are important in this process, in which the age $0-2$ years is defined as the so-called sensorimotor intelligence stage - the age at which a person learns through direct experience. In turn, from the second to the sixth year of life, we are dealing with the preoperative stage, where experimenting with objects is of major importance for development (Harwas-Napierała B., Trempała J., 2014). Therefore, in order to develop certain habits, the necessary elements must be introduced into the permanent environment, so that they later become something natural.

On this basis, a thesis can be drawn that the best moment to start building ecological awareness is the period of early childhood, and the best places are kindergartens or nurseries, taking into account their culture-forming and opinion-forming nature and the amount of time children spend in them. In addition, research indicates that the relationship with nature is deeper in people who during their childhood were closer to nature and spent more time in it. It is also worth noting that preschool children express their willingness to stay in facilities that at the same time provide access to elements such as greenery, water, uneven terrain, or even contact with animals ${ }^{8}$. In Poland, the subject of green areas next to "early childhood" facilities is not discussed too often, and it is definitely not one of the most important elements of human development. Researchers Emilia and Jan Frątczak emphasized the great importance of setting up gardens at kindergartens, and already in 1977, they published the book "Kindergarten Garden" describing the essence of the formation of these spaces 

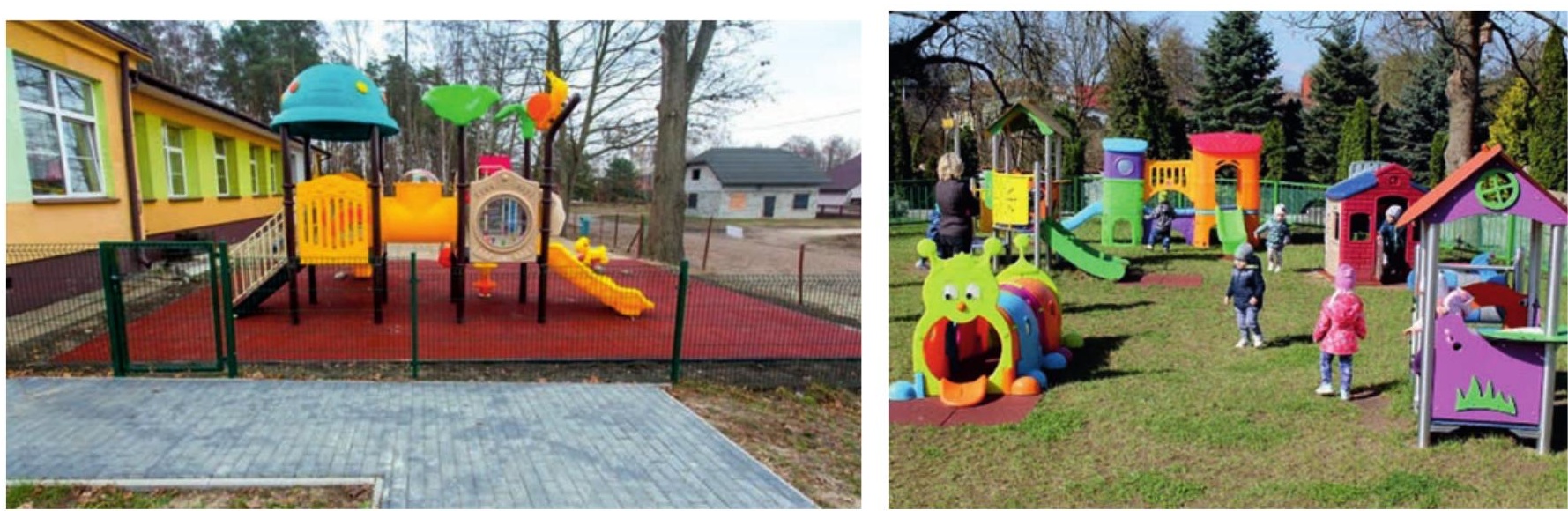

II. 1a. Plac zabaw przy jednym z przedszkoli samorządowych w Nowym Grabiu / A playground at one of the public kindergartens in Nowy Grab [źródło: https://www.gabin.pl/aktualnosci/854-nowy-plac-zabaw-dla-dzieci-uczeszczajacych-do-zlobka-samorzadowego-w-nowym-grabiu (data dostępu: 11.04.2021r.) ]

II. 2a. Plac zabaw przy jednym z przedszkoli samorządowych w Suwałkach / A playground at one of the public kindergartens in Suwalki [źródło: http://dwutygodniksuwalski.pl/aktywni-rodzice-szczesliwe-dzieci/ (data dostępu: 11.04.2021r.)]

jem i dostępem do nowych technologii, przestrzenie dla najmłodszych powinny dawać szansę celebrowania dzieciństwa poprzez obcowanie z przyrodą. Odbieranie tej możliwości w pierwszych latach życia jest przedwczesnym zabieraniem tego, co i tak sukcesywnie odbierać będzie dorosłość, a co kształtowało człowieka od wieków.

Dwa powyższe przykłady (il.1 i il.2.), choć z różnych miast, przedstawiają bardzo częste zestawienie kolorystyczne stosowane w Polsce zarówno zewnątrz jak i wewnątrz obiektów. Łączenie pastelowych zieleni, róży i żółcieni na elewacji wynika zazwyczaj z przekonania, które bardzo często można usłyszeć od dyrektorów placówek bądź urzędników z wydziału inwestycji - architektura dla dzieci ma być wesoła i kolorowa. Przekonanie to jest coraz częściej poddawane w wątpliwość zarówno przez badaczy jak i projektantów, a najnowsze trendy w architekturze pokazują, że budynki żłobków i przedszkoli nie powinny być przeskalowanym domkiem dla lalek, a funkcjonalną architekturą dla małych, ciekawych świata ludzi. W tej samej myśli projektowane powinny być ogrody, które pojawiają się zazwyczaj jedynie jako wydzielony fragment trawnika z katalogowym placem zabaw (il.1a i 1.2a) has shaped a person for centuries.

The two examples above (fig. 1 and ill. 2), although from different cities, present a very frequent combination of colors used in Poland, both inside and outside the buildings. The combination of pastel green, rose and yellow on the façade usually results from the belief that can often be heard from directors of institutions or officials from the investment department - architecture for children should be cheerful and colorful. This belief is more and more often questioned by both researchers and designers, and the latest trends in architecture show that the buildings of nurseries and kindergartens should not be scaled-up dollhouses, but functional architecture for small people curious about the world. Gardens should be designed in the same way, which usually appear only as a separate part of a lawn with a catalog playground (figures $1 \mathrm{a}$ and $1.2 \mathrm{a}$ )

\section{CITY KINDERGARTEN NO. 20 IN SOSNOWIEC}

Between a small residential area and the "Niwka" mining machinery factory, the existing municipal nursery was modernized and extended (fig. 3). The new shape

II. 3. Warto zwrócić uwagę, że w zagospodarowaniu terenu przedszkola w Sosnowcu nie użyto standardowych, katalogowych placów zabaw a skupiono się na naturze i wykorzystaniu rzeźby terenu oraz formacji ścian / It is worth noting, that the project does not include standard, catalog playgrounds, but focuses on the nature and use of terrain and wall formations [źródło: https://architektura.muratorplus.pl/realizacje/miejskie-przedszkole-w-sosnowcu_9976.html] (data dostępu: 15.02.2021r.)

II. 4. Postawę proekologiczną w bardzo udany sposób buduje u dzieci szklarnia, gdzie mogą obserwować proces wzrostu roślin / The greenhouse builds an ecological attitude in children, where they can observe the plant growth process [źródło: http://www.aimarchitekci.pl/projekty/ przedszkole-nr-20-w-sosnowcu,62 ] (data dostępu: 15.02.2021 r.)
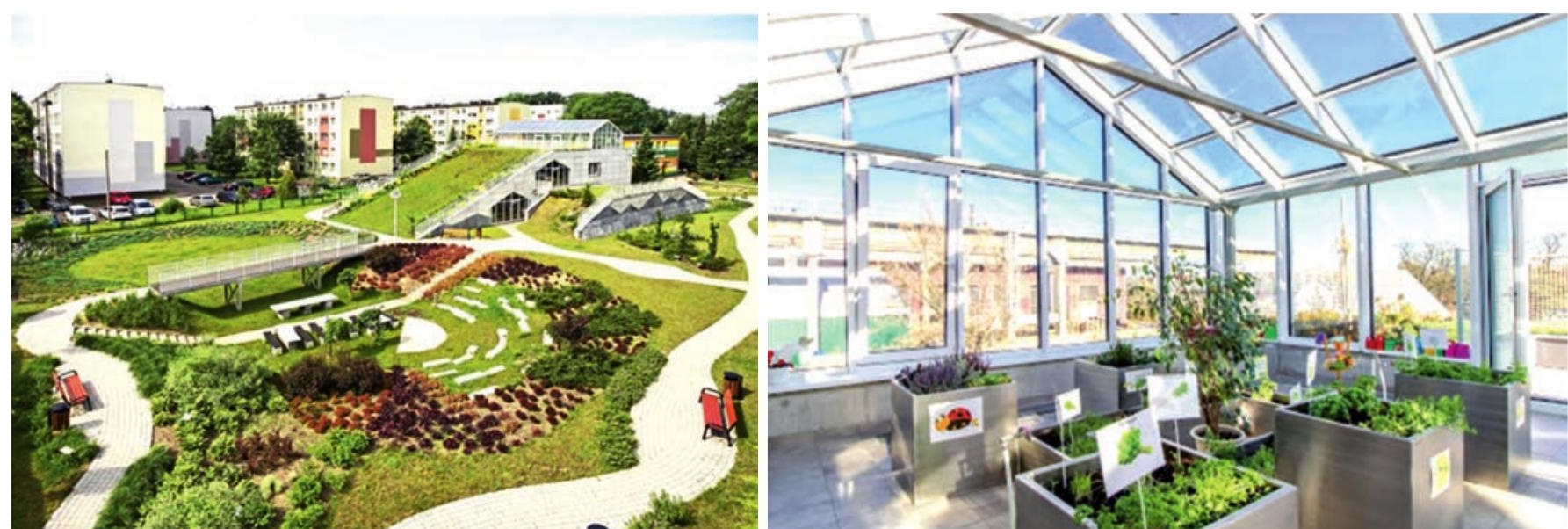
dzanych badań ${ }^{13}$ nie potwierdziło tej teorii, wykazując, że budowanie skojarzeń kolorystycznych jest indywidualne w początkowych fazach rozwoju a czerń może urozmaicić i podkreślić wnętrze (o ile oczywiście stanowi akcent a nie dominantę miejsca na stały pobyt ludzi).

\section{MIEJSKI ŻŁOBEK W GUASTALLA (WŁOCHY)}

Żłobek projektu Mario Cucinella Architects z 2015 r. w Guastalla - niewielkiej włoskiej miejscowości - położony jest wśród niskiej zabudowy jednorodzinnej. To przykład, gdzie zarówno bryła jak i wnętrza stymulują interakcję dziecka z otaczającą przestrzenią. Całe założenie jest zgodne z teorią nauczania, w której nic nie jest pozostawione przypadkowi - od rozmieszczenia stref edukacyjnych, po wybór materiałów konstrukcyjnych - i tym właśnie charakteryzuje się tzw. Metoda Reggio Emilia ${ }^{14}$. Wszelki dobór materiałów w budynku, organizacja miejsca czy doznania sensoryczne (dźwięk, światło, kolory, dotyk), które są tak ważne dla człowieka (J. Pallasmaa, 2012), zostały zaprojektowane z uwzględnieniem poszczególnych pedagogiczno-wychowawczych etapów rozwoju dziecka. W konstrukcji zastosowano naturalne materiały o niewielkim wpływie na środowisko, m.in. ramy z drewna klejonego, które stanowią również bardzo bezpieczną i ciekawą strukturę poprzez jej obłe formy (il. 6). Żłobek został wyposażony także w panele fotowoltaiczne czy zaawansowane systemy zbierania wody deszczowej a przeszklenia usytuowano tak, aby straty ciepła były jak najmniejsze. Tym samym dzieci od najmłodszych lat mogą dorastać w duchu ekologii i świadomości, że architektura i jej forma również ma ogromny wpływ na otaczającą przyrodę (il. 7). Wnętrze budynku zostało zaprojektowane w taki sposób aby maksymalnie pobudzić i rozwijać kreatywność oraz zainteresować dzieci otaczającym światem. Obiekt nie ma typowego układu wydzielonych pomieszczeń, a przechodząc z jednej strefy do kolejnej, najmłodsi użytkownicy mogą zatrzymać się przy „ścieżce edukacyjnej”, która odkrywa przed nimi ciekawe informacje. Większość przegród jest przeszklona, lecz posiada także kryjówki pozwalające na chowanie się, zabawę czy obserwacje innych grup dzieci. W budynku znajdziemy również wpisane $\mathrm{w}$ architekturę istniejące drzewa, które nie zostały usunięte tworząc tym samym niewielkie zielone enklawy uczące poszanowania natury. initial stages of development, and black can diversify and emphasize the interior (if, of course, it is an accent not a dominant feature of a place where people stay permanently).

\section{PUBLIC NURSERY IN GUASTALLA}

The nursery school in Guastalla - a small Italian town in Reggio Emilia community - is located in the midst of low-rise detached houses. It is a very interesting example where both the structure and the interiors stimulate the interaction of the child with the surrounding space. The whole concept follows a teaching theory in which nothing is left to chance - from the layout of the learning zones to the choice of construction materials - and this is what the so-called Reggio Emilia ${ }^{13}$ method is all about. All the choice of materials in the building, the organization of the space or the sensory experiences (sound, light, colors, touch) which are so important for human beings (J. Pallasmaa, 2012) have been designed taking into account the different pedagogical and educational stages of a child's development. Natural materials with low environmental impact have been used in the construction, such as glued wood frames, which are also a very safe and interesting structure through their rounded forms. The nursery is also equipped with photovoltaic panels and advanced rainwater harvesting systems, and the windows are located in such a way as to minimize heat loss. In this way, children can grow up from an early age with an ecological mindset and an awareness that architecture and its form also have a huge impact on the surrounding nature. The interior of the building has been designed in such a way as to maximally stimulate and develop the creativity and interest of children in the surrounding world. The building does not have a typical layout of separate rooms, and while moving from one zone to another, the youngest users may stop at the "educational path", which reveals interesting information to them. Most of the partitions are glazed, but there are also hiding places to hide, play or observe other groups of children. The building also incorporates existing trees into the architecture, which have not

II. 7. Widok wnętrza przedszkola w Guastalla w konstrukcji z drewna klejonego będącej jednocześnie elementami wykończenia / View of the interior of the kindergarten in Guastalla in a structure made of glued wood which is also a finishing element [ źródło: https://www.archdaily. com/775276/nido-dinfanzia-a-guastalla-mario-cucinella-architects] (data dostepu: 14.02.2021r. )

II. 8. Widok na zewnętrze bryły przedszkola Guastalla, gdzie wyraźnie widać rytm drewnianych ram oraz drzewa wpisane w rzut budynku / A view of the exterior of the Guastalla kindergarten, where the rhythm of the wooden frames and the trees is inscribed in the building plan [źródło: https:// www.archdaily.com/775276/nido-dinfanzia-a-guastalla-mario-cucinella-architects] (data dostępu: 14.02.2021r. )
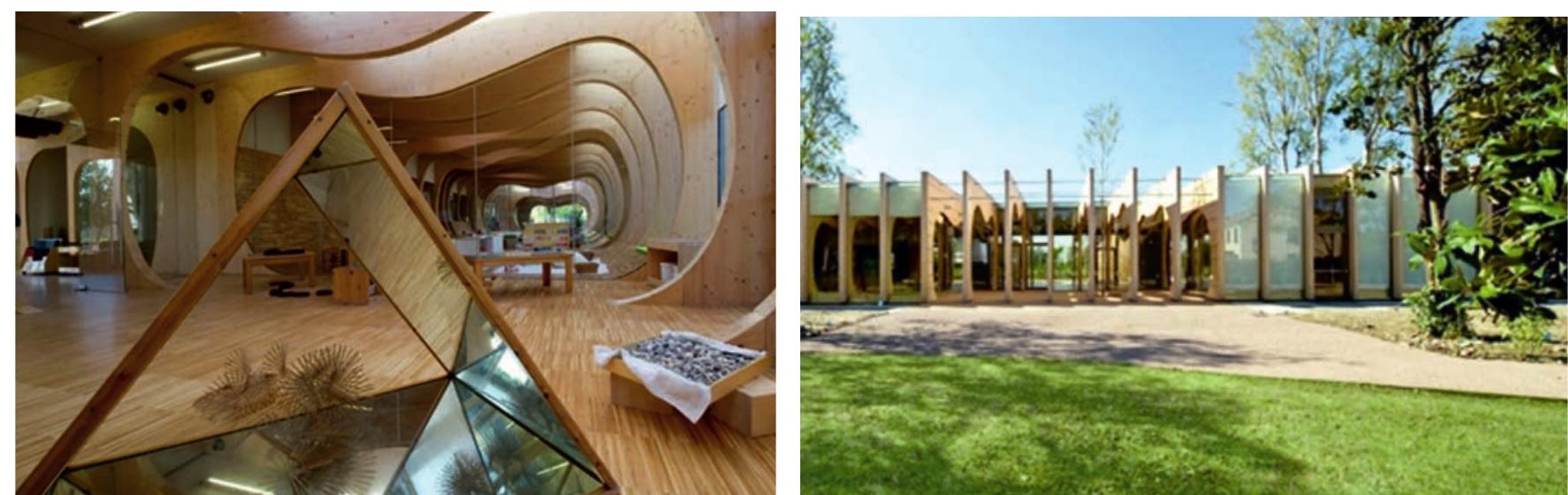
Architektura i otoczenie żłobków czy przedszkoli jest zatem idealnym miejscem aby stworzyć przyszłym pokoleniom środowisko w którym będą mogły cieszyć się dzieciństwem i przyrodą zanim wkroczą w nieunikniony świat najnowszych technologii i cywilizacyjnego pędu.

\section{PRZYPISY}

${ }^{1}$ Wypowiedź Davida Attenborough zacytowana w artykule z 2013 roku "Securing Nature's Future" przez Matta Adama Williamsa [źródło: https:// theecologist.org/2013/apr/04/securing-natures-future] (data dostępu: 27.01.2021r.)

2 David Attenborough - brytyjski biolog (ukończył zoologię w Clare College na Uniwersytecie Cambridge i studia podyplomowe $w$ dziedzinie antropologii), popularyzator wiedzy przyrodniczej na świecie, pisarz, narrator i podróżnik

${ }_{3}^{3}$ Autorka powołuje się na liczne artykuły i materiały niemające charakteru naukowego, publikowane w ogólnodostępnych mediach, które mają charakter opiniotwórczy.

${ }^{4}$ Artykut "Mental health benefits of interactions with nature in children and teenagers: a systematic review" autorstwa S. Tillmann, D. Tobin, W. Avison oraz J. Gilliland który podemuje próbe oceny i wpływy różnych form kontaktu z naturą na jakość samopoczucia i zdrowia psychicznego u dzieci. ${ }^{5}$ Zdrowie psychiczne jest dynamicznym stanem wewnętrznej równowagi, która umożliwia osobom wykorzystywanie ich umiejętności w harmonii z uniwersalnymi wartościami społecznymi. Podstawowe umiejętności poznawcze i społeczne; zdolność rozpoznawania, wyrażania i modulowania własnych emocji, a także współczucia dla innych; elastyczność i zdolność radzenia sobie z niekorzystnymi zdarzeniami w życiu i pełnienia funkcji w rolach społecznych; a także harmonijny związek między ciałem a umysłem to istotne składniki zdrowia psychicznego, które przyczyniają się w różnym stopniu do stanu równowagi wewnętrznej [za:] Silvana Galderisi i współautorzy ,Propozycja nowej definicji zdrowia psychicznego" <http:// www.psychiatriapolska.pl/uploads/images/PP_3_2017/407Galderisi_PsychiatrPol2017v51i3.pdf > [dostęp: 18.02.2021 r. ]

6 Jakość życia to stopień zaspokojenia materialnych i niematerialnych potrzeb jednostki i grup społecznych. Określaja ja zarówno czynniki obiektywne, np. przeciętne trwanie życia, zasięg ubóstwa, poziom skolaryzacji, jak i subiektywne, np. poziom szczęścia, stres czy sens życia" [Nowy leksykon PWN 1998, Warszawa, Wydawnictwo Naukowe PWN].

${ }_{7} \mathrm{Na}$ podstawie badań opisanych w artykule J. Skibskiej „Neuroplastyczność mózgu wsparciem rozwojowym dziecka we wczesnym dzieciństwie" ${ }^{8}$ Na podstawie badań wśród grupy przedszkolnej z którą autorka realizowała półroczne warsztaty architektoniczne w Samorządowym Przedszkolu nr 55 w Krakowie (w ramach współpracy z Narodowym Centrum Kultury "Archiprzygody")

${ }_{9}^{\prime A}$ Artykut A. Klichowskiej "Architektura i funkcje ogrodu przedszkolnego w opiniach nauczycieli" opisujący problematykę zieleni wokół terenów przedszkolnych.

${ }^{10}$ Badania będące częścią artykułu A. Klichowskiej „Architektura i funkcje ogrodu przedszkolnego w opiniach nauczycieli" (str. 328-332) dotyczące postawy nauczycieli wobec ogrodów przedszkolnych j.w.

${ }^{11}$ Projekt pracowni AiM Architekci ( projekt koncepcyjny, budowlany i wykonawczy 2015-2016 r. , realizacja budynku: 2016 - 2017 r.)

12 Wygrany projekt konkursowy pracowni architektonicznej xystudio (projekt : 2017 r., realizacja: 2019 r.

13 „Preferencje barw są cechą indywidulaną, mimo wielu badań w tym obszarze nie ma jednoznacznych wyników, co do np. barwy najpiękniejszej czy najbrzydszej. Można podjać próbe systematyzacji problemu ale jak wynika z doświadczeń, tylko dla danej populacji i w określonej sytuacji. Wspólna natomiast dla przeważającej większości badań jest obserwacja, iż harmonia barw budzi przyjemne odczucia, a dysharmonia - przykre." [cyt. : Starzyk A. (2017) Barwa w architekturze dla dzieci jako element kształtowania przyjaznych wnętrz, w Zeszyty Naukowe Uczelni Vistula, < http://cejsh.icm.edu.pl/cejsh/element/bwmeta1. element.desklight-f28ae942-a893-4ef2-adf4-867d546b7402> dostęp [13.02.2021r.]

14 Metoda Reggio Emilia wywodzi się od nazwy włoskiego regionu w którym powstała, a zainicjowana była przez pedagoga Lorisa Malguzziego (1920-1994) po II wojnie światowej. Na skutek migracji i urbanizacji oraz coraz bardziej powszechnego podejmowania pracy zawodowej przez kobiety pojawiła się potrzeba zorganizowania placówek pełniących opiekę nad małymi dziećmi. Metoda miała być oparta przede wszystkim na traktowaniu dziecka jako odrebnej, myślącej jednostki oraz zastapieniu odgórnego programu nauczania indywidualnym podejściem do podopiecznych. Liczne problemy formalne nie przeszkodziły w dalszej perspektywie a Metoda Reggio Emilia jest dziś jedną z najbardziej popularnych i uznawanych metod edukacji na etapie wczesnego nauczania.

15 Tezuka Architects- biuro architektoniczne założone przez Takaharu i Yui Tezuka w 1994 roku w Tokio, zajmujące się projektowaniem przede wszystkim szkół, biurowców i szpitali. stress. A phone or a tablet providing only two stimuli (visual and auditory), while proper human development requires a much more extensive sensory range. The architecture and surroundings of nurseries and kindergartens are therefore an ideal place to create an environment for future generations in which they will be able to enjoy childhood and nature before they enter the inevitable world of the latest technologies and civilization rush.

\section{ENDNOTES}

'Statement by David Attenborough quoted in the 2013 article "Securing Nature's Future" by Matt Adam Williams [source: https:// theecologist.org/2013/apr/04/securing-natures-future] (accessed 27.01.2021)

2 David Attenborough - British biologist (graduated in zoology from Clare College, University of Cambridge and postgraduate studies in anthropology), populariser of natural knowledge in the world, writer, narrator and traveller

${ }^{3}$ Autorka powołuje się na liczne artykuły i materiały niemające charakteru naukowego, publikowane w ogólnodostepnych mediach, które mają charakter opiniotwórczy.

${ }^{4}$ Article "Mental health benefits of interactions with nature in children and teenagers: a systematic review" by S. Tillmann, D. Tobin, W. Avison oraz J. Gilliland that attempts to assess the impact of various forms of contact with nature on the well-being and mental health of children.

${ }_{5}^{5}$ Mental health is a dynamic state of internal balance that enables individuals to use their skills in harmony with universal social values. Basic cognitive and social skills; the ability to recognise, express and modulate one's own emotions, as well as to empathise with others; flexibility and the ability to cope with adverse life events and function in social roles; and a harmonious relationship between body and mind are essential components of mental health that contribute in varying degrees to a state of internal balance [after Silvana Galderisi et al. "Proposal for a new definition of mental health" < http://www.psychiatriapolska.pl/uploads/images/ PP 3_2017/407Galderisi_PsychiatrPol2017v51i3.pdf > [accessed 18.02.2021 ]. [dostęp: 18.02.2021 r. ]

6 "Quality of life is the degree of satisfaction of material and non-material needs of individuals and social groups. It is determined by both objective factors, e.g. the average life expectancy, the scope of poverty, the level of schooling, and subjective factors, e.g. the level of happiness, stress or the sense of life". [Nowy leksykon PWN 1998].

${ }^{7}$ Based on the research described in the article by J. Skibska "Neuroplasticity of the brain as a developmental support for the child in early childhood"

8 Based on research among a group of pre-school children with whom the author conducted six-month architectural workshops at Kindergarten No. 55 in Cracow (as part of cooperation with the National Cultural Centre "Archiprzygody")

9 Article by A. Klichowska "Architecture and functions of pre-school gardens in teachers' opinions" describing the problem of greenery around pre-school areas

${ }^{10}$ Research being a part of the article by A. Klichowska " Architecture and functions of pre-school gardens in teachers' opinions" (pp. 328-332) concerning teachers' attitudes towards pre-school gardens 11 Winning competition project by architecture studio xystudio (design : 2017, implementation: 2019 )

12 "Colour preferences are an individual feature, and despite many studies in this area, there are no clear results as to which colours are the most beautiful or the ugliest. An attempt can be made to systematise the problem, but as experience shows, only for a given population and in a specific situation. However, common to the vast majority of studies is the observation that colour harmony evokes pleasant feelings, and disharmony - unpleasant ones." [cited. : Starzyk A. (2017) Barwa w architekturze dla dzieci jako element kształtowania przyjaznych wnętrz, in Zeszyty Naukowe Uczelni Vistula, <http://cejsh.icm. edu.pl/cejsh/element/bwmeta1.element.desklight-f28ae942-a893-4ef2-adf4-867d546b7402> accessed [13.02.2021r].

13 The Reggio Emilia method is derived from the name of the Italian region in which it originated, and was initiated by educationalist Loris Malguzzi (1920-1994) after the Second World War. As a result of migration and urbanisation, and the increasing participation of women in the labour market, there was a need to organise childcare facilities for young children. The method was to be based above all on treating the child as a separate, thinking individual and replacing a top-down curriculum with an individual approach to the charges. Numerous formal problems did not stand in the way and the Reggio Emilia Method is today one of 
16 Przedszkole Fuji w Tachikawie, Tokio zostało wybudowane w 2007 roku. Budynek został wybrany jako najlepszy tego typu obiekt na świecie przez organizację OECD ( Organisation for Economic Co-operation and Development) w 2011 roku, uzyskał również wiele innych nagród w dziedzinie architektury m.in. w 2019 roku „The best architecture of the 21st century" przez The Guardian; w 2017 roku: Moriyama RAIC International Prize 2017; w 2007 roku: ACE Award Design Category przez Association for Children's Enviroment,

17 Metoda Montessori (od założycielki lekarki Marii Montessori 1870-1952) jest jednym z systemów wychowawczych stosowanych w przedszkolach (rzadziej w szkołach) polegającym na wszechstronnym rozwoju dziecka. Prowadzone latami przez lekarkę badania pozwoliły odkryć jakie elementy maja wyjątkowo dobry wpływ na rozwój dzieci oraz do jakich przedmiotów czy zabaw z chęcią wracały. Przestrzenie w których prowadzi się zajęcia tą metodą są wielofunkcyjne i otwarte, dzieci maja relatywnie duża dowolność i wybó w podejmowanych działaniach a typowe dla sal ławki czy krzesła zastąpione są dywanami i matami.

\section{LITERATURA}

[1] Alexander Ch., Ishikawa S., Silverstein M., Jacobson M., Fiksdahl - King I., Angel S. (2008) Język wzorców. Gdańskie Wydawnictwo Psychologiczne

[2] Blakemore, S.J. i Frith, U. (2008). Jak uczy się mózg. Kraków. Wydawnictwo Uniwersytetu Jagiellońskiego

[3] Galderisi S., Heinz A., Kastrup M., Beezhold J., Sartorius N., 2017, Propozycja nowej definicji zdrowia psychicznego, Psychiatria Polska [online], 51(3): 407-411, Dostępny w : http://psychiatriapolska.pl/ uploads/images/PP 3 2017/407Galderisi PsychiatrPol2017v51i3. pdf , [dostep: 19.04.2021r.]

[4] Harwas-Napierała B. , Trempała J. (2014) Psychologia rozwoju człowieka. Rozwój funkcji psychicznych. Warszawa. Wydawnictwo Naukowe PWN

[5] Klichowska A. (2013) Architektura i funkcje ogrodu przedszkolnego w opiniach nauczycieli w: Studia Edukacyjne, 2013, nr 26, Wydawnictwo Naukowe UAM < https://repozytorium.amu.edu.pl/ bitstream/10593/10112/1/317-336.pdf > [dostep: 10.02.2021]

[6] Louv R. (2014) Ostatnie dziecko lasu. Warszawa. Wydawnictwo Mamania

[7] Marshall, C. (2017) Montessori education: a review of the evidence base. npj Science Learn 2, 11 <https://doi.org/10.1038/s41539017-0012-7> [dostęp : 19.04.2021]

[8] Mohammadi M. , Deimary N. (2017) Architecture and its impact on children's happiness and satisfaction in the sport spaces, Journal of Engineering and Applied Sciences, 12: 3441-3445, <https://medwelljournals.com/abstract/?doi=jeasci.2017.3441.3445> [dostęp: 09.04.2021r.]

[9] Pallasmaa J. (2012) Oczy skóry, architektura i zmysły. Kraków. Instytut Architektury

[10] Skibska J. (2015) Neuroplastyczność mózgu wsparciem rozwojowym dziecka we wczesnym dzieciństwie w: Zeszyty Naukowe Wyższej Szkoły Humanitas. Pedagogika <http://cejsh.icm.edu.pl/ cejsh/element/bwmeta1.element.desklight-e8ec5bb9-6f18-47dc-9af6-939589584828> [ dostęp 10.02.2021]

[11] Starzyk A. (2017) Barwa w architekturze dla dzieci jako element kształtowania przyjaznych wnetrz, w Zeszyty Naukowe Uczelni Vistula, < http://cejsh.icm.edu.pl/cejsh/element/bwmeta1.element. desklight-f28ae942-a893-4ef2-adf4- 867d546b7402> [dostęp 13.02.2021r.]

[12] Stegelin, D. A. (2003). "Application of the Reggio Emilia approach to early childhood science

curriculum". Early Childhood Education Journal, 30(3), 163-169. $<$ https://www.researchgate.net/publication/226775055 Application_of_the_Reggio_Emilia_Approach_to_Early_Childhood_Science_Currículum > [dostęp: 19.04.2021r.]

[13] Tillmann S., Tobin D., Avison W., Gilliland J. (2018) „Mental health benefits of interactions with nature in children and teenagers: a systematic review J Epidemiol Community Health 2018; <https:// jech.bmj.com/content/72/10/958> [dostęp: 09.04.2021r.]

[14] Wells N., and Lekies K. (2006) "Nature and the Life Course: Pathways from Childhood Nature Experiences to Adult Environmentalism." Children, Youth and Environments, vol. 16, no. 1, 2006, pp. 1-24. JSTOR, <wWw.jstor.org/stable/10.7721/chilyoutenvi.16.1.0001>. [dostęp:17.04.2021]

[15] WHOQOL Group. The World Health Organisation quality of life assessment (WHOQOL): Position paper from the world health organisation. Soc. Sci. Med. 1995; 41: 1403-1409. <https://www.sciencedirect.com/science/article/abs/pii/027795369500112K?via\%3Dih ub > [dostęp: 21.04 .2021 r.]

[16] Williams M.A. (2013) "Securing Nature's Future”, <https://theecologist.org/2013/apr/04/securing-natures-future > [dostęp:19.04.2021] the most popular and recognised methods of early childhood education. 14 Fuji Kindergarten in Tokyo was built in 2007. The building was selected as the best of its kind in the world by the OECD ( Organisation for Economic Co-operation and Development) in 2011, and has won many other architecture awards including in 2019 "The best architecture of the 21st century" by The Guardian; in 2017: Moriyama RAIC International Prize 2017; in 2007: ACE Award Design Category by the Association for Children's Enviroment

15 Tezuka Architects- an architectural firm founded by Takaharu and Yui Tezuka in 1994 in Tokyo, primarily designing schools, office buildings and hospitals.

${ }^{16}$ The Montessori method (from the founder of the doctor Maria Montessori, 1870-1952) is one of the educational systems used in kindergartens (less often in schools) consisting in the comprehensive development of a child. The research conducted for years by the doctor made it possible to discover which elements have an exceptionally good impact on the development of children and to which items or games they would like to return. The spaces in which classes are conducted using this method are multifunctional and open, children have a relatively large freedom and choice (redrafting) in the activities they undertake, and the benches and chairs typical of the classrooms are replaced with carpets and mats.

\section{REFERENCES}

[1] Alexander Ch., Ishikawa S., Silverstein M., Jacobson M., Fiksdahl King I., Angel S. (2008) Język wzorców. Gdańskie Wydawnictwo Psychologiczne

[2] Blakemore, S.J. i Frith, U. (2008). Jak uczy się mózg. Kraków. Wydawnictwo Uniwersytetu Jagiellońskiego

[3] Galderisi S., Heinz A., Kastrup M., Beezhold J., Sartorius N., 2017, Propozycja nowej definicji zdrowia psychicznego, Psychiatria Polska [online], 51(3): 407-411, Dostępny w : http://psychiatriapolska.pl/uploads/ images/PP 3 2017/407Galderisi PsychiatrPol2017v51i3.pdf , [dostęp: 19.04.2021 $\bar{r}$.]

[4] Harwas-Napierała B. , Trempała J. (2014) Psychologia rozwoju człowieka. Rozwój funkcji psychicznych. Warszawa. Wydawnictwo Naukowe PWN

[5] Klichowska A. (2013) Architektura i funkcje ogrodu przedszkolnego w opiniach nauczycieli w: Studia Edukacyjne, 2013, nr 26, Wydawnictwo Naukowe UAM < https://repozytorium.amu.edu.pl/bitstream/10593/10112/1/317-336.pdf > [dostęp:10.02.2021]

[6] Louv R. (2014) Ostatnie dziecko lasu. Warszawa. Wydawnictwo Mamania

[7] Marshall, C. (2017) Montessori education: a review of the evidence base. npj Science Learn 2, 11 <https://doi.org/10.1038/s41539-017-00127> [dostep : 19.04.2021]

[8] Mohammadi M. , Deimary N. (2017) Architecture and its impact on children's happiness and satisfaction in the sport spaces, Journal of Engineering and Applied Sciences, 12: 3441-3445, <https://medwelljournals. com/abstract/?doi=jeasci.2017.3441.3445> [dostęp: 09.04.2021r.]

[9] Pallasmaa J. (2012) Oczy skóry, architektura i zmysły. Kraków. Instytut Architektury

[10] Skibska J. (2015) Neuroplastyczność mózgu wsparciem rozwojowym dziecka we wczesnym dzieciństwie w: Zeszyty Naukowe Wyższej Szkoły Humanitas. Pedagogika <http://cejsh.icm.edu.pl/cejsh/element/ bwmeta1.element.desklight-e8ec5bb9-6f18-47dc-9af6-939589584828> [ dostep 10.02.2021 ]

[11] Starzyk A. (2017) Barwa w architekturze dla dzieci jako element kształtowania przyjaznych wnętrz, w Zeszyty Naukowe Uczelni Vistula, http://cejsh.icm.edu.pl/cejsh/element/bwmeta1.element. desklight-f28ae942-a893-4ef2-adf4- 867d546b7402> [dostęp 13.02.2021r.]

[12] Stegelin, D. A. (2003). "Application of the Reggio Emilia approach to early childhood science

curriculum". Early Childhood Education Journal, 30(3), 163-169. <https:// www.researchgate.net/publication/226775055_Application_of_the_Reggio_Emilia_Approach_to_Early_Childhood_Science_Curriculum $>-{ }^{-}$[dostęp: $19.0 \overline{4} .2021$ r.]

[13] Tillmann S. Tobin D. Avison W. Gilliland J. (2018) Mental health benefits of interactions with nature in children and teenagers: a systematic review J Epidemiol Community Health 2018; <https://jech.bmj.com/ content/72/10/958 > [dostęp: 09.04.2021r.]

[14] Wells N., and Lekies K. (2006) "Nature and the Life Course: Pathways from Childhood Nature Experiences to Adult Environmentalism." Children, Youth and Environments, vol. 16, no. 1, 2006, pp. 1-24. JSTOR, <www. istor.org/stable/10.7721/chilyoutenvi.16.1.0001>. [dostep:17.04.2021]

[15] WHOQOL Group. The World Health Organisation quality of life assessment (WHOQOL): Position paper from the world health organisation. Soc. Sci. Med. 1995; 41: 1403-1409. <https://www.sciencedirect. com/science/article/abs/pii/027795369500112K?via\%3Dihub> [dostęp: 21.04.2021 r.]

[16] Williams M.A. (2013) "Securing Nature's Future", <https://theecologist.org/2013/apr/04/securing-natures-future > [dostęp:19.04.2021] 